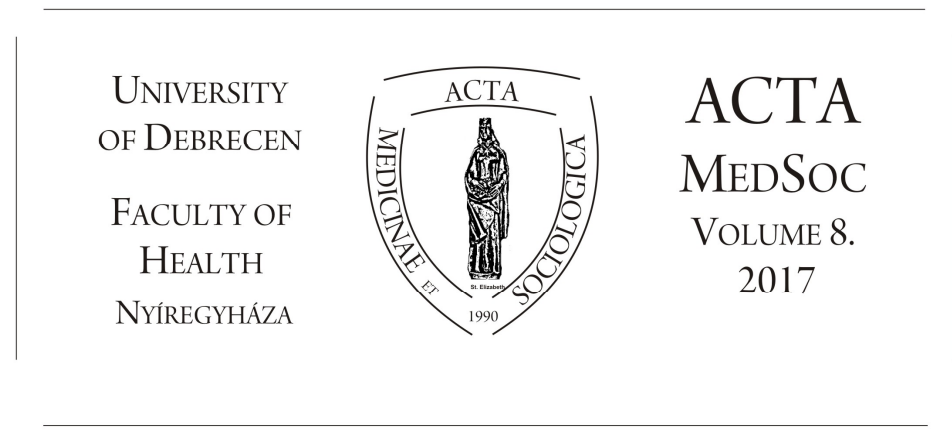

\title{
Szülésznők munkával való elégedettségének vizsgálata
}

\author{
Gebriné Éles Krisztina ${ }^{1}$, Takács Péter ${ }^{1}$, Kósa Zsigmond ${ }^{1}$, \\ Heinrichné Kőszegi Katalin ${ }^{1}$, Lampek Kinga ${ }^{2}$ \\ 1. Debreceni Egyetem Egészségügyi Kar, \\ 2. Pécsi Tudományegyetem Egészségtudományi Kar
}

\begin{abstract}
Absztrakt. Az egészségügyi dolgozók munkával való elégedettségét az utóbbi években többen is kutatták, bemutatták, jelen tanulmány a szülésznők munkával való elégedettségével foglalkozik.

Célkitüzés. A vizsgálat célja, a szülésznők munkával való elégedettségének felmérése az iskolai végzettség függvényében.

Anyag és módszer. Keresztmetszeti vizsgálat önkitöltős kérdőív alkalmazásával, az ország 13 kórházában dolgozó szülésznők körében. A kérdőivet már korábban alkalmazták az ápolók körében végzett hasonló felmérések során. A kérdőívek feldolgozása Evasys rendszerben történt, az eredmények statisztikai elemzése SPSS 23.0 program segítségével zajlott.

Eredmények. A szülésznők összességében szeretik a hivatásukat, a munkakörülményeiket többnyire megfelelőnek tartják, segítik egymást a munkavégzés során, de személyes problémáikat kevésbé beszélik meg kollégáikkal, kapcsolatuk általában a munkavégzésre korlátozódik, csak kevés szülésznő találkozik tervezetten munkahelyén kívül munkatársaival. Mindezek ellenére a pályaszeretetének hátterében álló okok között a második helyen a jó munkatársi kapcsolatokat tartják fontosnak a szülésznők. A szülésznői végzettség függvényében (,régi” OKJ végzettséget nem adó, OKJ, BSc képzés) nem találtunk szignifikáns eltéréseket a csoportok véleménye között. Hasonlóan vélekednek a
\end{abstract}


munkakörülményekröl, a munkahelyi légkörről. A hiányosságok is azonos téren jelentkeznek a munkával való elégedettségre vonatkozó válaszok alapján.

Következtetések. A munkával való elégedettség többféle aspektusát figyelembe véve a szülésznők, függetlenül attól, hogy milyen iskolai végzettséggel rendelkeznek alapvetöen elégedettek a munkakörülményeikkel, jó munkatársi kapcsolatokkal rendelkeznek. Munkahelyüktől, az alábbi téren szeretnének segítséget kapni: a továbbtanulás, a konferenciákon való részvétel munkáltatói támogatása, a dokumentációs terhek csökkentése, a gyógyszertámogatás, a gyógyászati segédeszközök támogatása (pl.szemüveg). Igen fontosnak tartják a válaszadók, a dolgozói létszám emelését, és a bérkérdést kritikusnak tartják a szülésznők. A munkavégzés körülményeinek javítására vonatkozó javaslataik között, a béren kívüli juttatások, a munkaruha vásárlás támogatása szerepelt. Második helyen, a konferenciákon, szakmai továbbképzéseken való részvétel támogatása, valamint a közös szabadidős programok szervezését tartanák még fontosnak, ahhoz hogy a munkahelyi légkör javuljon.

Kulcsszavak: szülésznők, munkával való elégedettség, támogatottság

\section{Abstract. Survey on the job satisfaction of midwifes.}

Many researchers has already dealt with the work satisfaction of the health workers in recent years. This study focuses with the midwives's work satisfaction.

Aim. The aim of the authors is to survey the satisfaction with the work of midwives based on their qualification.

Method. The cross-sectional study using a self-administrated questionnaire among midwives, in 13 hospitals in the country. The questionnaire has already been used in similar survey conducted among nurses. The questionnaires were processed in Evasys system, the statistical analysis of the results was conducted by using SPSS 23.0 software. Results. The midwives like their profession, their working conditions are mostly considered to be appropriate, they assist each other in the work, but personal problems are less discussed with their colleagues, their relationship is generally restricted to working, only a small number of midwives plan to meet their colleagues outside the workplace. Based on the midwifery degree course ("old" qualification, OKJ, BSc ) there were no significant differences in the opinion the groups. They regarded the working conditions and the work atmosphere similarly. On the basis of responses to satisfaction with work deficiences appeared int he same field.

Conclusion. Based on various aspects of satisfaction with the work of the midwives, with or without education, are basically satisfied with their working conditions, have good employee relations. Midwives would like to get help from their workplace int he following area: support for the further education and the conference participation, reduce the burden of the documentation, support for the pharmaceutical subsidy, and medical devices (eg.glasses). Importent the respondents consider the increase in the number of employees and the wage issue is critical for the midwives. Their proposal for improving working conditions includ fringe benefits, and the support of buying work clothes. In the second place, in order to improve the working atmosphere the support participations at conferences, training courses and recreational programs are considered to be important for midwives.

Keywords: midwife, work satisfaction, support

DOI: $10.19055 / \mathrm{ams} .2017 .8 / 24 / 4$ 


\section{Bevezetés}

Az egészségügyi dolgozók munkával való elégedettségét, a munkahelyi támogatottság mértékét már több neves szakember is vizsgálta, kutatta és publikálta hazánkban, az elmúlt évtizedben (Betlehem J. 2003, Németh A. 2010, Újváriné és mtasi. 2015). Ezen vizsgálatok az ápolók csoportjára fókuszáltak, a szülésznők a vizsgálatokba, mint egyéb egészségügyi dolgozók szerepeltek (Németh és Irinyi, 2011). Az általuk adott válaszokat külön nem elemezték a szerzők. Ezen a helyzeten szeretne változtatni a bemutatott kutatás.

\section{A szülésznők képzési és munkaügyi helyzete}

A szülésznők az egészségügy speciális területén dolgoznak, ahol nemcsak a betegekkel, azok ápolásával és gondozásával kell foglalkozniuk, hanem egészséges várandósok, szülőnők, gyermekágyasok ellátását és gondozását is végzik. Munkájuk természetéből adódóan lényegesen több sikerélmény és pozitív viszszajelzés éri/érheti őket a mindennapi munkavégzésük során. Ezen pozitív viszszajelzések jelentősen megnövelhetik a munkával való elégedettségük mértékét, valamint ellensúlyozhatják a negatív stresszorok hatását, így a kiégés jelenségének kialakulásában, pozitív késleltető tényezőként szerepelhetnek.

A szülésznők létszáma az ápolói létszámhoz viszonyítva hazánkban lényegesen kisebb, ennek ellenére a szülésznők mindig is markáns képviselőik voltak az egészségügynek, szakmájuknak. A Magyar Ápolási Egyesület Szülésznői Szekciójának vezetősége, rendszeres időközönként felméri a kórházakban dolgozó szülésznők létszámát, végzettségi szintek szerinti bontásban. A legutóbbi felmérés 2015 májusában történt, melynek adatai alapján 1625 szülésznő dolgozik az ellátó rendszerben (1. táblázat).

\begin{tabular}{|l|c|c|c|c|}
\hline Szülésznői végzettség & BSC & OKJ & Régi képzés & $\begin{array}{l}\text { Összlétszám(orsz.) } \\
\text { (tartósan távollevők:129) }\end{array}$ \\
\hline Létszám(fö) & 202 & 1132 & 319 & 1653 \\
\hline \%-os megoszlás & $12,22 \%$ & $68,48 \%$ & $19,30 \%$ & $100 \%$ \\
\hline
\end{tabular}

(Forrás: Csetneki J. 2015).

1. táblázat: Szülésznői létszám adatok végzettségi szintek szerint.

Magyarországon a szülésznők jelenleg többféle szülésznői képesítéssel rendelkezhetnek. Az idősebb korosztály esetében OKJ-s végzettséget nem adó képzések zajlottak (10 hónapos, 1 éves, szakosító képzés kertében). Ezek a képzések az 
1990-es évek elejére megszüntek és az 1994/95-ös tanévben elinduló szülésznőképzés során már OKJ-s végzettséget szerezhettek a hallgatók. A képzések nappali formában 3 éves időtartamban zajlottak, illetve párhuzamosan folyt a szülésznői HÍD képzés a régebbi szülésznő végzettségek, és az OKJ-s képzés közötti különbségek áthidalására. Ezek a képzések EU-konformnak minősültek, tehát az európai elvárásoknak feleltették meg a tananyagot és a gyakorlati órák számát. Később kreditrendszerbe is beilleszthetővé vált az OKJ képzés. 2006-ban indult el a föiskolai képzés, ugyanakkor megszünt az OKJ-s szülésznőképzés. Így a szülésznők 2006-tól már a Bolognai folyamatba bekapcsolódva BSc végzettséget szerezhettek és akár a következő lépcsőfokra, az MSc szintre is továbbléphetnek. A különböző végzettségü szülésznők között, hasonlóan az ápolók helyzetéhez, szintén nem különülnek el élesen a gyakorlatban a végzettségi szintekhez kapcsolható feladatkörök. Évekig még a fizetéskategóriákban sem volt különbség a végzettségi szintek között, a föiskolai végzettséggel rendelkező szülésznők nem kapták meg a diplomás alapbért, vagy a diplomás státuszt, sőt még napjainkban sem egységes a kórházakban a szülésznők besorolása és bérezése.

\section{Szakirodalmi áttekintés}

\section{A munkával való elégedettség}

A munkával való elégedettség fogalmának többfajta meghatározása ismert a szakirodalmakban. Guiot 1984-ben úgy fogalmazta meg a munkával való elégedettséget, hogy ha a dolgozó munkája kielégíti a legfontosabb szükségleteit, akkor munkahelyi elégedettségröl beszélünk, ellenkező esetben pedig elégedetlenségről (Guiot,1984). Pap és Perczel meghatározása szerint a munkával való elégedettség mindazon tényezők tudati reprezentálódása, amelyek a munkakör jellemzőiből adódnak, és amelyek tudati tükröződés útján a konkrét munkakörrel szembeni állásfoglalást befolyásolják (www.1).

A munkavégzés során a közérzet összefügg a viselkedéssel, tehát a munkájával elégedett ember többet és jobban fog dolgozni, mint aki elégedetlen. Az elégedetlen munkavállaló gyakrabban fog munkahelyet változtatni, többet hiányzik a munkahelyéröl, igyekszik a megélhetéséhez szükséges jövedelmet más forrásból megszerezni. Mivel a munkának nagy jelentősége van az emberek életében, a munkával való elégedettség része az élet minőségének, és hatással van fizikai és mentális közérzetünkre (Medgyesi és Róbert, 2000).

A munkaelégedettségre vonatkozó kutatások eredményeiből levonható az a megállapítás, hogy a személy és foglalkozása, munkamagatartása, illetve a munkának a személyre gyakorolt hatása között szoros összefüggés áll fenn. Ha a munkavállaló és a munkavégző szerep kínálta lehetőségek között megfelelő 
összhang alakul ki, akkor az szintén befolyásolja a munkateljesítményt. A munkájával elégedett dolgozó szívesebben tartózkodik a munkahelyén, jobb kedvvel végzi munkáját, mindez a munkahelyi teljesítmény javulásához is hozzájárul (Hasselhorn et al. 2005).

Az elégedettséget meg lehet határozni egy olyan munkával kapcsolatos pozitív érzésként is, ami az egyén munkával és munkatapasztalatával kapcsolatos értékeléséből keletkezik. A munkára vonatkozó tapasztalatokon alapul az értékelésnek, a hozzá való viszonyulásnak tekinthető a munkával való elégedettség, ami érzelmi vagy kognitív értékelésben fejeződik ki. Ez egyrészt a munkára, a munkahelyre adott pozitív vagy negatív érzelmi reagálás alapján alakul ki, másrészt az érzelem az elégedettség jelének is tekinthető. Amennyiben elégedett egy dolgozó, akkor kedvezően viszonyul a munkahelyéhez, ha elégedetlen, akkor kedvezőtlenül (Sass, 2011).

\section{A munkahelyi elégedettséget befolyásoló tényezők}

A munkahelyi elégedettséget, a munkával való elégedettséget számos tényező befolyásolja. Az évtizedek során kialakult elégedettség-elméletek elsősorban az egyéni, a szociális, a szervezeti és a környezeti tényezők szerepét elemezték, és próbálták meg ezeket egységesen kezelni.

Az idők során többféle olyan modell is megalkotásra került, melyekben a munkával kapcsolatos elégedettséget befolyásoló tényezők hatásait elemezték. Sass Judit munkájában összefoglalta ezen modelleket, melyekből a leglényegesebbeket emelném ki, úgymint Locke 1976-ban megalkotott modellét, amely azt írta le, hogy a munkának mely aspektusai a legfontosabbak a személy számára, ami az elégedettséget befolyásolja. A modell feltevése szerint nagy befolyásoló szerepe van a múltbeli tapasztalatnak és a másokkal való összehasonlításnak. Adams méltányossági elméletében az kerül leírásra, hogy ha a munkavégzés során, a várt és a tapasztalt haszon, vagy a befektetés kedvezőtlen irányban eltérnek, akkor valószínü az elégedetlenség kialakulása. Kiemelhető még Jex és Brit 2008-ban leírt elmélete, amely azt hangsúlyozza, hogy a fizetés kapcsán a munkatársakkal való összevetés is befolyásolja az elégedettséget. Néhány elmélet rámutat arra, hogy az elégedettség nagyban függ a munkavállaló személyiségétől is, hogy a pozitív érzelmi beállítódás, a pozitív affektivitás előre jelzi a munkával való elégedettséget. A munkahelyi érzelmek és az elégedettség összefüggését, sokrétű hatótényezővel együtt lehet értelmezni. Az elégedettséget előzményesen meghatározó munkahelyi tapasztalatot és az elégedettség következtében létrejövő érzelmek által kiváltott viselkedést egyaránt figyelembe kell venni. Kitérve azokra az egyéni és munkahelyi hatásokra, amelyek a munkahelyi érzelmi tapasztalattal összefüggenek (Sass, 2011).

Az elmúlt évtizedekben sok munkával való elégedettség kutatásának kiinduló elméletét adta a Herzberg és munkatársai által leírt motiváció-elmélet, mely a 
Maslowi szükséglet piramis hierarchia modelljére épült. Ennek alapja az, hogy az ember elöször az alapvető szükségleteinek kielégitésére törekszik, majd amikor ezeket kielégítette, akkor kezd el a magasabb szükségletek kielégítésére törekedni. Herzberg úgy véli, hogy a modern társadalmakban az alapvető szükségletek kielégítése mindenkinél megvalósul, ezért az alacsonyabb szintủ szükségletek kielégítése még nem vezet megelégedettségre, legfeljebb a munkával szembeni közömbös attitüd kialakulására. Az alapvető szükségletek ki nem elégítettsége viszont feltétlenül elégedetlenséghez vezet. A munkával való elégedettség alapvetően a magasabb rendü szükségletek kielégítésétől függ. Herzberg azokat a tényezőket, amelyek a munkával való megelégedéshez vezetnek,- mint az érdekes, a képességeket próbára tevő tevékenységek,- motivátoroknak nevezte el. Véleménye szerint a munkával való elégedettség, az előzőeken kívül, az egészségtani tényezőktől is nagymértékben függ, valamint a fizikai környezet, a munkatársak, és a munkahelyi vezetők hatása is jelentős paraméterként jelentkezik (www.1).

Az elméletek sorában meg kell még említeni, mint talán az egyik legáttekinthetőbb módon megalkotott modell, Warr vitamin modelljét, melyben a fizikai tényezők, a fizetés és a szociális pozíció jelentik a $\mathrm{C}$ és $\mathrm{E}$ vitamint, melyek nagy mennyiségben sem mérgezőek, tehát ezek a tényezők kevésbe rontják a munkahelyi elégedettséget. A munka $\mathrm{v}$ áltozatossága, az ellenőrzés mértéke, az interperszonális kapcsolatok mértéke, a szükséges készségek mennyisége jelentik az A és a D vitamint. Ezek kis mennyiségben is negatívan befolyásolhatják a munkaelégedettséget, ha e tényezök körében negatív tapasztalat alakul ki az a munkával valóelégedettséget is nagyban ronthatja (Németh, 2013).

\section{A vizsgálat célja}

A bemutatott vizsgálat célja, a szülésznők munkával való elégedettség jellemzöinek feltárása. A cél megvizsgálni, mely tényezők befolyásolják a szakdolgozók munkával való elégedettségét. A vizsgálat kiterjedt arra, hogy a szakmai végzettség szintje meghatározó tényezője-e a munkahelyi elégedettségnek. A kérdőíves módszer az elégedettséget befolyásoló tényezők többféle dimenzióját is vizsgálta, úgymint a munkatársi kapcsolatokat, a vezetés jellegét, a fizetést és a munkahelyi légkört. 


\section{Anyag és módszer}

A kutatás során keresztmetszeti vizsgálatra került sor 2016-ban, önkitöltős kérdőív alkalmazásával, az ország 13 kórházában dolgozó szülésznők körében. A kérdőívet már korábban alkalmazták az ápolók körében végzett felmérések során (Németh és mtsai. 2010). A kérdőíveket a nyíregyházi, a kisvárdai, két debreceni, két miskolci, a bajai, a pécsi, a szombathelyi, a székesfehérvári, a kecskeméti, a gyulai kórházakban, valamint egy budapesti kórházban, a fekvőbeteg ellátásban dolgozó különböző szülésznői végzetséggel rendelkező szakdolgozók töltötték ki.

A kérdőívek feldolgozása Evasys programmal, az adatok statisztikai elemzése SPSS 23.0 statisztikai programmal történt. Leíró statisztikai módszerekkel, kereszttáblákkal, a khí-négyzet próbát alkalmazva történt meg az eredmények elemzése. A megbízhatósági tartományt (MT) 95\%-ban határoztuk meg. A kérdőív kérdései a munkával való elégedettség többféle aspektusát is lefedték, úgy mint a fizikai környezet, a munkahelyi légkör, a munkatársakkal való kapcsolattartás, a kereset, a munkához való viszonyulás. A kérdésekben állítások hangzottak el, amelyekkel való egyetértést jelölhették a válaszadók. Az egyetértésük mértékét 1-5 terjedő Likert skálán tudták jelölni, ahol az 1- az egyáltalán nem ért egyet, az 5 pedig a teljes mértékben való egyetértést fejezte ki. Az egyetértés és az iskolai végzettség közötti kapcsolat vizsgálata kereszttáblás elemzéssel, khinégyzet próbával történt.

\section{Eredmények}

255 kitöltött kérdőívre alapozva, súlyozott adatbázist alakítottunk ki, ami már az iskolai végzettség szerinti megoszlás arányában a populációs arányokat követi (1. táblázat).

\begin{tabular}{|l|c|c|c|c|}
\hline Szülésznői végzettség & BSC & OKJ & „Régi képzés” & $\begin{array}{l}\text { Összlétszám (saját) } \\
\text { N=245 fŏ }\end{array}$ \\
\hline létszám & 35 & 163 & 47 & 245 \\
\hline \%-os megoszlás & $14,2 \%$ & $66,7 \%$ & $19,1 \%$ & $100 \%$ \\
\hline
\end{tabular}

2. táblázat: A szülésznők végzettség szerinti megoszlása a kérdőívet kitöltők körében.

A kérdőív első 3 három kérdése a munkahelyi légkör, valamint a kollégákkal való kapcsolat megítélésére vonatkozott (3. táblázat). A kapott eredmények azt 
mutatják, hogy a szülésznők többsége megfelelőnek, barátságosnak tartja a légkört amiben dolgozik, a megkérdezettek 40,8\%- a eléggé barátságosnak ítélte meg, 31,3\% szerint nagyon barátságos a munkahelyi légkör (összesen72,1\%). Az eredmények azt mutatják, hogy van egy része a dolgozóknak, akik nem teljesen elégedettek, a válaszadók $21,9 \%$-a csak részben elégedett a munkahelyi légkörrel, 0,8\%-a kismértékben, 1,4\%-a egyáltalán nem tartja barátságosnak a munkahelyi légkört (összesen 24,1\%).

A következő kérdés arra vonatkozott, hogy a szülésznő kollégák milyen gyakran segítenek egymásnak abban, hogy jobban végezzék a munkájukat. A munkavégzés során a válaszadók többsége szerint $(39,9 \%)$ eléggé jellemző az, hogy segítik egymást a szülésznők, (az 5 fokozatú skálán a 4-es értéket jelölték be) és $(36,2 \%)$ pedig az 5-ös értéket jelölte, amely érték a nagyfokú segítőkészséget mutatja a munkatársak között. (összesen 76,1\%). A harmadik kérdés arra vonatkozott, hogy mennyire tudják a szülésznő munkatársakkal megbeszélni a problémáikat. A válaszok alapján az látható, hogy a szülésznők személyes problémáikat nagyrészt meg tudják egymás között beszélni, de nem teljes mértékben, a legtöbben az eléggé választ jelölték meg (32,0\%). Több negatív választ adtak ennél a kérdésnél a szülésznők, mint az előző kettőnél, összesen 30 fő az, aki csak kismértékben, vagy egyáltalán nem beszéli meg személyes problémáit munkatársaival (összesen 11,9\%)

\begin{tabular}{|l|c|c|c|c|c|}
\hline $\begin{array}{l}\text { Kérdések: } \\
\mathrm{N}=248\end{array}$ & $\begin{array}{l}\text { egyáltalán } \\
\text { nem }\end{array}$ & $\begin{array}{l}\text { kis } \\
\text { mértékben }\end{array}$ & valamennyire & eléggé & nagyon \\
\hline $\begin{array}{l}\text { Mennyire tartja ba- } \\
\text { rátságosnak a lég- } \\
\text { kört amelyben dol- } \\
\text { gozik? }\end{array}$ & $\begin{array}{c}4 \\
(1,4 \%)\end{array}$ & $\begin{array}{c}2 \\
(0,8 \%)\end{array}$ & $\begin{array}{c}56 \\
(21,9 \%)\end{array}$ & $\begin{array}{c}104 \\
(40,8 \%)\end{array}$ & $\begin{array}{c}80 \\
(31,3 \%)\end{array}$ \\
\hline $\begin{array}{l}\text { Szülésznö kollégái } \\
\text { milyen gyakran } \\
\text { segítenek abban, } \\
\text { hogy jobban végezze } \\
\text { a munkáját? }\end{array}$ & $\begin{array}{c}4 \\
(1,4 \%)\end{array}$ & $\begin{array}{c}11 \\
(4,2 \%)\end{array}$ & $\begin{array}{c}39 \\
(15,4 \%)\end{array}$ & $\begin{array}{c}102 \\
(39,9 \%)\end{array}$ & $\begin{array}{c}92 \\
(36,2 \%)\end{array}$ \\
\hline $\begin{array}{l}\text { Milyen gyakran } \\
\text { tudja Ön személyes } \\
\text { problémáit kollégái- } \\
\text { val megbeszélni? }\end{array}$ & $(3,9 \%)$ & $\begin{array}{c}20 \\
(8,0 \%)\end{array}$ & $\begin{array}{c}53 \\
(20,7 \%)\end{array}$ & $\begin{array}{c}94 \\
(32,0 \%)\end{array}$ & \begin{tabular}{c}
$(27,1 \%)$ \\
\hline
\end{tabular}
\end{tabular}

3. táblázat. Munkahelyi légkör, kollégákkal való kapcsolat megítélése.

A válaszokat a végzettségi csoportok körében vizsgálva, azt az eredményt kaptuk, hogy az első kérdésre adott válaszok tekintetében, a csoportok véleménye 
nem különbözött $\left(\chi^{2}(8, N=231)=9,574\right.$ p=0,296), jellemzően a pozitív vélemények voltak túlsúlyban, az 5-ös és a 4-es értéket választották a legtöbben, de ez nem volt szignifikáns különbség. A második kérdésnél, a csoportok véleménye között szintén nem mutatható ki szignifikáns különbség, $\left(\chi^{2}(8, N=235)=6,361\right.$ p $=$ 0,607), a harmadik kérdés, ami a személyes problémák szülésznő társakkal való megbeszélésére irányult, szintén nem mutatott a csoportok közötti véleménykülönbségek terén szignifikáns eltérést $\left(\chi^{2}(8, N=233)=11,14 \mathrm{p}=0,195\right)$. A legtöbb negatív vélemény, az OKJ-s végzettségü csoportban lett megjelölve, itt a válaszadók 10,0\%-a csak kismértékben és 4,4\% egyáltalán nem tudja megbeszélni problémáit szülésznő társaival (4. táblázat).

\begin{tabular}{|c|c|c|c|c|}
\hline \multicolumn{2}{|c|}{$\begin{array}{l}\text { Végzettség } \\
\text { szerinti cso- } \\
\text { portok }\end{array}$} & $\begin{array}{l}\text { Mennyire tartja } \\
\text { barátságosnak a } \\
\text { légkört amelyben } \\
\text { dolgozik? } \\
\text { NS }\end{array}$ & $\begin{array}{l}\text { Szülésznő társai } \\
\text { milyen gyakran } \\
\text { segítenek abban, } \\
\text { hogy jobban végez- } \\
\text { ze a munkáját? } \\
\text { NS }\end{array}$ & $\begin{array}{l}\text { Milyen gyakran tudja } \\
\text { személyes problémáit } \\
\text { szülésznő társaival } \\
\text { megbeszélni? } \\
\text { NS }\end{array}$ \\
\hline \multirow{5}{*}{$\begin{array}{l}\text { „régi } \\
\text { képzés” } \\
\mathrm{N}=45\end{array}$} & 1. & $13(28,9 \%)$ & $14(31,1 \%)$ & $12(26,7 \%)$ \\
\hline & 2. & $22(48,9 \%)$ & $20(44,4 \%)$ & $17(37,8 \%)$ \\
\hline & 3. & $8(17,8 \%)$ & $7(15,6 \%)$ & $15(33,3 \%)$ \\
\hline & 4. & $1(2,2 \%)$ & $4(8,9 \%)$ & $0(0,0 \%)$ \\
\hline & 5. & $1(2,2 \%)$ & $0(0,0 \%)$ & $1(2,2 \%)$ \\
\hline \multirow{5}{*}{$\begin{array}{l}\text { OKJ } \\
\mathrm{N}=160\end{array}$} & 1. & $48(30,4 \%)$ & $62(38,5 \%)$ & $47(29,4 \%)$ \\
\hline & 2. & $66(41,8 \%)$ & $66(41,0 \%)$ & $62(38,8 \%)$ \\
\hline & 3. & $42(26,6 \%)$ & $23(14,3 \%)$ & $28(17,5 \%)$ \\
\hline & 4. & $0(0,0 \%)$ & $6(3,7 \%)$ & $16(10,0 \%)$ \\
\hline & 5. & $2(1,3 \%)$ & $4(2,59 \%)$ & $7(4,4 \%)$ \\
\hline \multirow{5}{*}{$\begin{array}{l}\mathrm{BSc} \\
\mathrm{N}=28\end{array}$} & 1. & $12(42,9 \%)$ & $12(41,4 \%)$ & $6(21,4 \%)$ \\
\hline & 2. & $9(32,1 \%)$ & $12(41,4 \%)$ & $12(42,9 \%)$ \\
\hline & 3. & $5(17,9 \%)$ & $5(17,2 \%)$ & $7(25,0 \%)$ \\
\hline & 4. & $1(3,6 \%)$ & $0(0,0 \%)$ & $3(10,7 \%)$ \\
\hline & 5. & $1(3,6 \%)$ & $0(0,0 \%)$ & $0(0,0 \%)$ \\
\hline
\end{tabular}

4. táblázat. Munkahelyi légkör, kollégákkal való kapcsolat megítélése iskolai végzettség szerinti csoportokban.

A kérdöív következő 8 kérdése, a munka szeretetére, a végzett munkával való elégedettségre, illetve a munkára való alkalmasság érzetére vonatkozó állításokat tartalmazott. Az értékelés során 2 csoportot hoztunk létre az egyetértést kifejező körbe a „nagyon egyetért” és az „egyetért” válaszok, a nem ért egyet csoportba pedig a „nem ért egyet” és az „egyáltalán nem ért egyet” válaszlehetőségek kerültek. A „régi képzésben” résztevő szülésznők 69,8\%-a, az OKJ végzettségüek 
76,6\%-a és a BSc végzettségüek 82,8\%-a, egyetértett azzal az állítással, hogy nagyon élvezik a munkájukat. Azzal pedig hogy, „ha újra választana, akkor nem a szülésznői munkát választaná", a régi képzésben résztvevők 45,2\%-a, az OKJ végzettségüek 50,7\%-a, nem értett egyet. (5. táblázat).

\begin{tabular}{|c|c|c|c|c|c|c|}
\hline \multirow{3}{*}{$\begin{array}{l}\text { Tételek: } \\
\text { Mennyire ért } \\
\text { egyet az alábbi } \\
\text { állításokkal? }\end{array}$} & \multicolumn{3}{|c|}{ Egyetért* } & \multicolumn{3}{|c|}{ Nem ért egyet** } \\
\hline & \multicolumn{3}{|c|}{ Végzettségszerinti csoportok } & \multicolumn{3}{|c|}{ Végzettség szerinti csoportok } \\
\hline & $\begin{array}{l}\text { „régi” } \\
\text { képzés }\end{array}$ & OKJ & $\mathrm{BSC}$ & $\begin{array}{l}\text { régi } \\
\text { képzés }\end{array}$ & OKJ & $\mathrm{BSC}$ \\
\hline $\begin{array}{l}\text { 1.Nagyon élve- } \\
\text { zem a munkámat } \\
\text { NS }\end{array}$ & $\begin{array}{c}30 \\
(69,8 \%)\end{array}$ & $\begin{array}{c}121 \\
(76,6 \%)\end{array}$ & $\begin{array}{c}24 \\
(82,8 \%)\end{array}$ & $\begin{array}{c}1 \\
(2,3 \%)\end{array}$ & $\begin{array}{c}7 \\
(3 \%)\end{array}$ & $\begin{array}{c}0 \\
(0,0 \%)\end{array}$ \\
\hline $\begin{array}{l}\text { 2.Ha újra válasz- } \\
\text { tanék másfajta } \\
\text { munkát végeznék }\end{array}$ & $\begin{array}{c}12 \\
(28,6 \%)\end{array}$ & $\begin{array}{c}0 \\
(0,0 \%)\end{array}$ & $\begin{array}{c}0 \\
(0,0 \%)\end{array}$ & $\begin{array}{c}19 \\
(45,2 \%)\end{array}$ & $\begin{array}{c}90 \\
(50,7 \%)\end{array}$ & $\begin{array}{c}18 \\
(7,9 \%)\end{array}$ \\
\hline $\begin{array}{l}\text { 3.Más szülész- } \\
\text { nőknél jobban } \\
\text { szeretem a mun- } \\
\text { kámat NS }\end{array}$ & $\begin{array}{c}12 \\
(28,6 \%)\end{array}$ & $\begin{array}{c}55 \\
(36,4 \%)\end{array}$ & $\begin{array}{c}9 \\
(31 \%)\end{array}$ & $\begin{array}{c}13 \\
(31 \%)\end{array}$ & $\begin{array}{c}37 \\
(24,5 \%)\end{array}$ & $\begin{array}{c}8 \\
(27,6 \%)\end{array}$ \\
\hline $\begin{array}{l}\text { 4.Ritkán unom a } \\
\text { munkámat NS }\end{array}$ & $\begin{array}{c}23 \\
(54,8 \%)\end{array}$ & $\begin{array}{c}84 \\
(54,9 \%)\end{array}$ & $\begin{array}{c}16 \\
(55,2 \%)\end{array}$ & $\begin{array}{c}12 \\
(28,6 \%)\end{array}$ & $\begin{array}{c}38 \\
(24,8 \%)\end{array}$ & $\begin{array}{c}9 \\
(31 \%)\end{array}$ \\
\hline $\begin{array}{l}\text { 5.Nem foglalko- } \\
\text { zom azzal a } \\
\text { gondolattal, hogy } \\
\text { más munkát } \\
\text { keressek NS }\end{array}$ & $\begin{array}{c}22 \\
(52,4 \%)\end{array}$ & $\begin{array}{c}71 \\
(46,4 \%)\end{array}$ & $\begin{array}{c}14 \\
(50,1 \%)\end{array}$ & $\begin{array}{c}9 \\
(21,4 \%)\end{array}$ & $\begin{array}{c}48 \\
(31,4 \%)\end{array}$ & $\begin{array}{c}10 \\
(35,7 \%)\end{array}$ \\
\hline $\begin{array}{l}\text { 6.Legtöbbször } \\
\text { lelkesít a mun- } \\
\text { kám NS }\end{array}$ & $\begin{array}{c}26 \\
(60,5 \%)\end{array}$ & $\begin{array}{c}100 \\
(63,3 \%)\end{array}$ & $\begin{array}{c}20 \\
(69 \%)\end{array}$ & $(7,0 \%)$ & $\begin{array}{c}14 \\
(8,9 \%)\end{array}$ & $\begin{array}{c}1 \\
(3,4 \%)\end{array}$ \\
\hline $\begin{array}{l}7 . \text { Valószínűleg } \\
\text { nem vagyok } \\
\text { igazán alkalmas } \\
\text { a munkámmal } \\
\text { járó tevékeny- } \\
\text { ségre NS }\end{array}$ & $\begin{array}{c}2 \\
(4,7 \%)\end{array}$ & $\begin{array}{c}7 \\
(4,6 \%)\end{array}$ & $\begin{array}{c}0 \\
(0,0 \%)\end{array}$ & $\begin{array}{c}39 \\
(90,7 \%)\end{array}$ & $\begin{array}{c}135 \\
(88,2 \%)\end{array}$ & $\begin{array}{c}25 \\
(89,3 \%)\end{array}$ \\
\hline $\begin{array}{l}\text { 8.Meglehetősen } \\
\text { elégedett vagyok } \\
\text { a munkámmal } \\
\text { NS }\end{array}$ & $\begin{array}{c}19 \\
(45,2)\end{array}$ & $\begin{array}{c}97 \\
(63,0)\end{array}$ & $\begin{array}{c}19 \\
(67,9)\end{array}$ & $\begin{array}{c}4 \\
(9,5)\end{array}$ & $\begin{array}{c}16 \\
(10,4)\end{array}$ & $\begin{array}{c}1 \\
(3,6)\end{array}$ \\
\hline
\end{tabular}

5. táblázat. Munkával való elégedettség, alkalmasság érzésének megítélése, No(\%). 
A következő kérdés arra irányult, hogy milyen mértékben tartják egymással a kapcsolatot munkahelyükön kívül a szülésznők. Válaszukat egy 1-6 terjedő Likert skálán jelölték meg. Az első csoportba a szülésznők 51,1\%-a, a második csoportból 46\%-a a harmadik csoportból pedig 39,3\% -a jelölte meg a „kevesebb mint havonta egyszer", választ. A végzettségi csoportok között nem mutatkozott szignifikáns különbség, $\mathrm{x}^{2}(10, \mathrm{~N}=231)=4,683 \mathrm{p}=0,911$ (6. táblázat)

\begin{tabular}{|c|c|c|c|c|c|c|}
\hline \multirow{2}{*}{ 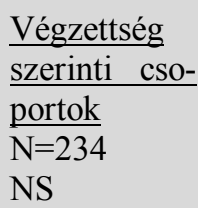 } & \multicolumn{6}{|c|}{ Milyen gyakran találkozik szülésznő társaival munkahelyén kívül? } \\
\hline & $\begin{array}{l}\text { 6-szinte } \\
\text { minden } \\
\text { nap }\end{array}$ & $\begin{array}{l}5- \\
\text { hetente2-6 } \\
\text { alkalom }\end{array}$ & $\begin{array}{l}\text { 4-hetente } \\
\text { egyszer }\end{array}$ & $\begin{array}{l}\text { 3-kb. } \\
\text { havonta } \\
\text { egyszer }\end{array}$ & $\begin{array}{l}\text { 2-kevesebb } \\
\text { mint havon- } \\
\text { ta egyszer }\end{array}$ & 1-soha \\
\hline $\begin{array}{l}\text { „régi kép- } \\
\text { zés” }\end{array}$ & $\begin{array}{c}2 \\
(4,4 \%)\end{array}$ & $\begin{array}{c}2 \\
(4,4 \%)\end{array}$ & $\begin{array}{c}3 \\
(6,7 \%)\end{array}$ & $\begin{array}{c}11 \\
(24,4 \%)\end{array}$ & $\begin{array}{c}23 \\
(51,1 \%)\end{array}$ & $\begin{array}{c}4 \\
(8,9 \%)\end{array}$ \\
\hline $\mathrm{OKJ}$ & $\begin{array}{c}6 \\
(3,7 \%)\end{array}$ & $\begin{array}{c}10 \\
(6,2 \%)\end{array}$ & $\begin{array}{c}12 \\
(7,5 \%)\end{array}$ & $\begin{array}{c}36 \\
(22,4 \%)\end{array}$ & $\begin{array}{c}74 \\
(46 \%)\end{array}$ & $\begin{array}{c}23 \\
(14,3 \%)\end{array}$ \\
\hline $\mathrm{BSc}$ & 0 & $\begin{array}{c}2 \\
(7,1 \%)\end{array}$ & $\begin{array}{c}4 \\
(14,3 \%)\end{array}$ & $\begin{array}{c}6 \\
(21,4 \%)\end{array}$ & $\begin{array}{c}11 \\
(39,3 \%)\end{array}$ & $\begin{array}{c}5 \\
(17,9 \%)\end{array}$ \\
\hline
\end{tabular}

6. táblázat. Kapcsolattartás a munkatársak között.

A kérdőív 3 kérdése vonatkozott a bérezéssel, a fizetéssel való megelégedettségre, ahol 1-5 terjedő Likert skálán jelölték a válaszadók azt, hogy milyennek ítélik meg a szülésznői bérüket a környezetükben élő emberekéhez, egyéb egészségügyi dolgozókéhoz és más kórházakban dolgozó szülésznőkéhez képest. Az eredmények azt mutatják, hogy a környezetükben élő emberekéhez viszonyítva, a fizetésüket mindhárom csoportból inkább átlagon alulinak, illetve némiképp megfelelönek ítélték meg (7. táblázat).

\begin{tabular}{|c|c|c|c|c|c|}
\hline \multirow{2}{*}{$\begin{array}{l}\text { Végzettség } \\
\text { szerinti } \\
\text { csoportok }\end{array}$} & \multicolumn{5}{|c|}{$\begin{array}{l}\text { A környezetében élö emberekhez képest hogyan ítéli meg a } \\
\text { jövedelmét? }\end{array}$} \\
\hline & $\begin{array}{l}\text { jelentősen } \\
\text { átlagon aluli }\end{array}$ & átlagon aluli & $\begin{array}{l}\text { némiképp } \\
\text { megfelelö }\end{array}$ & $\begin{array}{l}\text { átlagon } \\
\text { felüli }\end{array}$ & $\begin{array}{l}\text { jelentősen } \\
\text { átlagon felüli }\end{array}$ \\
\hline „,régi képzés” & $11(25 \%)$ & $12(25 \%)$ & $19(43,2 \%)$ & $2(4,5 \%)$ & 0 \\
\hline OKJ & $39(25,3 \%)$ & $39(25,3 \%)$ & $64(64,0 \%)$ & $1(0,6 \%)$ & $4(2,6 \%)$ \\
\hline $\mathrm{BSc}$ & $2(7,1 \%)$ & $2(7,1 \%)$ & $17(60,7 \%)$ & $1(3,6 \%)$ & 0 \\
\hline
\end{tabular}

7. táblázat. Jövedelem megítélése a megkérdezett szülésznők körében. 
A keresetre vonatkozó kérdésekre a válaszokat 1-5-ig terjedő skálán tudták megadni. A megkérdezettek.1- es az egyáltalán nem megfelelö, az 5-ös pedig a nagyon megfelelő értékelést jelentette. A más intézményben dolgozó szülésznők keresetéhez viszonyítva megfelelőnek ítélték meg fizetésüket a válaszadók. Végzettség szerint itt nem mutatkozott szignifikáns különbség $\left(\chi^{2}(8, N=225)=10,142 \mathrm{p}=0,255\right)$. A keresetre vonatkozó 3. kérdésben, pedig arra válaszoltak a szülésznők, hogy a más egészségügyi dolgozókéhoz viszonyítva milyennek ítélik meg a saját keresetüket. Itt már mutatkozott eltérés a csoportok véleménye között $\left(\chi^{2}(8, N=227)=23,582 \mathrm{p}=0,003\right)$. A ,régi képzés" csoportba tartozók 42,2\%-a „,némiképp megfelelőnek”, 26,7\%-a „nem megfelelőnek", és 24,1\%-a ,egyáltalán nem megfelelőnek” tartja a keresetét. Az OKJvégzettségüek 40,0\%-a ,nem megfelelőnek” 21,3\%-a ,egyáltalán nem megfelelőnek" tartja keresetét ebben az összehasonlításban, a BSc végzettséggel rendelkező szülésznők véleménye eltérö, 59,3\%-uk gondolja „némiképp megfelelőnek”, 18,5\%-uk pedig „,megfelelőnek” keresetét más egészségügyi dolgozókéhoz viszonyítva (8. táblázat).

\begin{tabular}{|c|c|c|c|}
\hline \multicolumn{2}{|c|}{$\begin{array}{l}\text { Végzettség } \\
\text { szerinti } \\
\text { csoportok }\end{array}$} & $\begin{array}{l}\text { Mennyire tartja megfelelönek } \\
\text { keresetét más egészségügyi } \\
\text { intézménnyel összehasonlítva? }\end{array}$ & $\begin{array}{l}\text { Mennyire tartja megfelelőnek } \\
\text { keresetét más egészségügyi } \\
\text { dolgozókkal összehasonlítva? }\end{array}$ \\
\hline \multirow{5}{*}{$\begin{array}{l}\text { „régi } \\
\text { képzés „, }\end{array}$} & 1 & $13(29,5 \%)$ & $11(24,1 \%)$ \\
\hline & 2 & $11(25 \%)$ & $12(26,7 \%)$ \\
\hline & 3 & $18(40,9 \%)$ & $19(42,2 \%)$ \\
\hline & 4 & $2(4,5 \%)$ & $2(4,4 \%)$ \\
\hline & 5 & $0(0,0 \%)$ & $1(2,2 \%)$ \\
\hline \multirow{5}{*}{ OKJ } & 1 & $38(24,7 \%)$ & $33(21,3 \%)$ \\
\hline & 2 & $58(37,7 \%)$ & $62(40,0 \%)$ \\
\hline & 3 & $46(29,9 \%)$ & $53(34,2 \%)$ \\
\hline & 4 & $11(7,1 \%)$ & $7(4,5 \%)$ \\
\hline & 5 & $1(0,6 \%)$ & $0(0,0 \%)$ \\
\hline \multirow{5}{*}{$\mathrm{BSc}$} & 1 & $4(14,8 \%)$ & $3(11,1 \%)$ \\
\hline & 2 & $6(22,2 \%)$ & $3(11,1 \%)$ \\
\hline & 3 & $13(48,1 \%)$ & $16(59,3 \%)$ \\
\hline & 4 & $4(14,8 \%)$ & $5(18,5 \%)$ \\
\hline & 5 & $0(0,0 \%)$ & $0(0,0 \%)$ \\
\hline
\end{tabular}

8. táblázat. Jövedelem megítélése a kérdőívet kitöltők körében No(\%)

A következő 5 kérdés a munkaválasztás, és a pályaválasztás hátterében rejlő okokra irányult. 1-5-ig terjedö Likert skálán jelölték a véleményüket a válaszadók. Az alsó két és a felső három kategóriát összevonva történtek a további 
elemzések. A végzettség szerint ezekben a kérdésekben nem mutatkozott szignifikáns különbség (9. táblázat).

\begin{tabular}{|c|c|c|c|c|c|c|}
\hline \multirow{3}{*}{$\begin{array}{l}\text { Tételek: } \\
\text { Az alábbi tényezők } \\
\text { mekkora szerepet jät- } \\
\text { szanak abban,hogy Ön } \\
\text { a szülésznői pályán } \\
\text { dolgozik }\end{array}$} & \multicolumn{3}{|c|}{ Szerepet játszik benne* } & \multicolumn{3}{|c|}{$\begin{array}{l}\text { Nem játszik benne szere- } \\
\text { pet** }\end{array}$} \\
\hline & \multicolumn{3}{|c|}{ Végzettségszerinti csoportok } & \multicolumn{3}{|c|}{ Végzettség szerinti csoportok } \\
\hline & $\begin{array}{l}\text { „régi” } \\
\text { képzés }\end{array}$ & OKJ & BSC & $\begin{array}{l}\text { „,régi” } \\
\text { képzés }\end{array}$ & OKJ & $\mathrm{BSC}$ \\
\hline $\begin{array}{l}\text { 1.A munkában rejlő } \\
\text { kihívás }\end{array}$ & $\begin{array}{c}14 \\
(32,6 \%)\end{array}$ & $\begin{array}{c}47 \\
(30,3 \%)\end{array}$ & $\begin{array}{c}7 \\
(24,1 \%)\end{array}$ & $\begin{array}{c}29 \\
(67,4 \%)\end{array}$ & $\begin{array}{c}108 \\
(69,7 \%)\end{array}$ & $\begin{array}{c}22 \\
(75,9 \%)\end{array}$ \\
\hline $\begin{array}{l}\text { 2.Nincs más elhelyez- } \\
\text { kedési lehetősége }\end{array}$ & $\begin{array}{c}34 \\
(79,1 \%)\end{array}$ & $\begin{array}{c}113 \\
(73,4 \%)\end{array}$ & $\begin{array}{c}25 \\
(89,3 \%)\end{array}$ & $\begin{array}{c}9 \\
(20,9 \%)\end{array}$ & $\begin{array}{c}41 \\
(26,6 \%)\end{array}$ & $\begin{array}{c}3 \\
(10,7 \%)\end{array}$ \\
\hline $\begin{array}{l}\text { 3.A rászoruló emberek } \\
\text { segítése }\end{array}$ & $\begin{array}{c}10 \\
(23,3 \%)\end{array}$ & $\begin{array}{c}50 \\
(32,7 \%)\end{array}$ & $\begin{array}{c}7 \\
(25,0 \%)\end{array}$ & $\begin{array}{c}33 \\
(76,7 \%)\end{array}$ & $\begin{array}{c}103 \\
(67,3 \%)\end{array}$ & $\begin{array}{c}21 \\
(75,0 \%)\end{array}$ \\
\hline $\begin{array}{l}\text { 4. A megélhetés forrá- } \\
\text { sa }\end{array}$ & $\begin{array}{c}20 \\
(47,6 \%)\end{array}$ & $\begin{array}{c}84 \\
(54,5 \%)\end{array}$ & $\begin{array}{c}17 \\
(58,6 \%)\end{array}$ & $\begin{array}{c}22 \\
(52,4 \%)\end{array}$ & $\begin{array}{c}70 \\
(45,5 \%)\end{array}$ & $\begin{array}{c}12 \\
(41,4 \%)\end{array}$ \\
\hline $\begin{array}{l}\text { 5.A jó munkatársi } \\
\text { kapcsolatok }\end{array}$ & $\begin{array}{c}21 \\
(50,0 \%)\end{array}$ & $\begin{array}{c}70 \\
(45,5 \%)\end{array}$ & $\begin{array}{c}20 \\
(69,0 \%)\end{array}$ & $\begin{array}{c}21 \\
(50,0 \%)\end{array}$ & $\begin{array}{c}84 \\
(54,5 \%)\end{array}$ & $\begin{array}{c}9 \\
(31,0 \%)\end{array}$ \\
\hline
\end{tabular}

9. táblázat: A pályaválasztást befolyásoló tényezők a megkérdezettek körében.

Az utolsó kérdés arra irányult, hogy összességében, minden tényezőt figyelembe véve mennyire elégedettek a szülésznői munkájukkal a megkérdezettek. Véleményüket 1-5 terjedő Likert skálán jelölték, ahol az 1- az egyáltalán nem elégedett, az 5-a nagyon elégedett véleményt jelentette. Ebben a kérdésben az első és a második választási lehetőséget senki nem jelölte meg. A „régi képzés"-be tartozó szülésznők legtöbben az elégedett választ jelölték meg (50,0\%) de 47,7\%- uk csak részben elégedett. Az „OKJ”-s csoportba sorolt válaszadók 66,0\%-a részben elégedett. A „BSc” csoportból pedig, 79,3\%-ban választották a részben elégedett lehetőséget, és senki nem választotta azt, hogy nagyon elégedett a munkájával. A képzettség szerinti összehasonlítás itt már szignifikáns különbséget jelzett. $\left(\chi^{2}(4, N=229)=11,789 \mathrm{p}=0,019\right)$ (10. táblázat). 


\begin{tabular}{|l|c|l|c|}
\hline \multirow{2}{*}{$\begin{array}{l}\text { Végzettség szerinti } \\
\text { csoportok }\end{array}$} & \multicolumn{3}{|c|}{$\begin{array}{l}\text { Mindent figyelembe véve mennyire érzi magát elégedettnek } \\
\text { szülésznői munkájával? }\end{array}$} \\
\cline { 2 - 4 } & nagyon elégedett & elégedett & részben elégedett \\
\hline \multirow{2}{*}{ „régi képzés” } & $1(2,3 \%)$ & $22(50,0 \%)$ & $21(47,7 \%)$ \\
\hline OKJ & $9(5,8 \%)$ & $44(28,2 \%)$ & $103(66,0 \%)$ \\
\hline BSc & 0 & $6(20,7 \%)$ & $23(79,3 \%)$ \\
\hline
\end{tabular}

10. táblázat. Szülésznői munkával való elégedettség a megkérdezett szülésznők között, No(\%).

\section{Összegzés}

Először történt a szülésznők körében ilyen vizsgálat, melynek során, a munkával való elégedettség többféle összetevője is vizsgálatra került: munkahelyi légkör, munkatársakkal való kapcsolattartás, munkavégzéssel való elégedettség, jövedelem megítélése, pályaválasztás, pálya szeretete mögött álló tényezők. A kiindulási hipotézis azt feltételezte, hogy ezen tényezőkön belül vannak eltérések a különböző szintü szülésznői végzettséggel rendelkező szülésznők véleménye között. Ezt indokolhatják a generációs különbségek is.

Az eredmények szerint a különböző végzettségü csoportok igen nagy hasonlóságot mutattak. A három csoport az elégedettség részleteit vizsgáló kérdések körében, csak a más egészségügyi dolgozókkal való kereseti különbségek megítélésében mutatott szignifikáns különbséget.

A szülésznői munkával való elégedettség (összefogó kérdés) tekintetében viszont a csoportok szignifikáns eltérést mutattak. Ez az eredmény arra enged következtetni, hogy a csoportok közötti elégedettségi különbségeket más faktorok bevonásával kell megközelíteni. Ez további vizsgálatokat igényel a területen.

\section{Irodalomjegyzék}

1. Aiken L.H, Clarke S.P, Sloane D.M, Sochalski J.A, Busse R., Clarke H.,....Shamian J. (2001): Nurses'Reports On Hospital Care In Five Countres, Health Affairs 20(3). 43-53.

2. Aiken L.H., Sloane D.M., Bruyneel L., Koen Van den Heede, Sermeus W., (2012): Nurses'reports of working conditions and hospital quality of care 
in 12 countries in Europe, International Journal of Nursing Studies 50(2013) 143-153.

3. Betlehem J. (2006): A fizetett és nem fizetett munka hatása az ápolók életminőségére különböző klinikai környezetben. Doktori (PhD) értekezés.

4. Csetneki J. (2015): Szülésznők Magyarországon e. a. XXIII. Országos Szülésznői Konferencia, Budapest, 2015.május 14-16.

5. Csetneki J. (2015): A szülésznők helyzete Magyarországon. A létszám adatok alakulása, Ápolásügy 2015. 29. évf. 3. szám.

6. Guiot J.M. (1984): Szervezetek és magatartásuk. (pp.172-193). Budapest, Közgazdasági és Jogi Könyvkiadó.

7. Győrffy Zs., Molnár R., Somorjai N. (2012): Gyógyítók helyzete és egészsége-a magyarországi vizsgálatok szakirodalmi áttekintése, Mentálhigiéné és Pszichoszomatika 13. (2012) 2, 107-126.

8. Hasselhorn M.H., Tackenberg P., Buescher A., Simon M., Kuemmerling A., Mueller B.H. (2005): Work and health of nurses in Europe results from the NEXT - Study, In.: http://www.next.uni-wuppertal.de/ NE/ index.php ?articles-and-reports (letöltés dátuma: 2017.01.15.)

9. Medgyesi M., Róbert P. (2000): A munkával való elégedettség nemzetközi összehasonlításban, In: Társadalmi Riport 2000, Budapest TÁRKI, Pp. 591-616.

10. Németh A. (2013): Fekvőbeteg ellátásban dolgozó ápolónők munkával való elégedettségének követéses országos vizsgálata, valamint jól-létének (WELL-BEING) alakulása a változó hazai egészségügyi rendszerben. Doktori $(\mathrm{PhD})$ értekezés.

11. Németh A. (2013): Az egészségügyi dolgozók munkaelégedettségét befolyásoló tényezők, Nővér, 2013, 26(4), 27-31.

12. Németh A., Betlehehem J., Lampek K. (2014): Ápolók romló egészségi állapota, Nővér, 2014, 27(3), 18-22.

13. Németh A., Irinyi T. (2009): Egészségügyi dolgozók egészségmagatartása, orvoshoz fordulási szokásai Csongrád megyében. Nővér XXII. évf., 4.sz. 32-38.

14. Perczel T.: Motiváció,megelégedettség, beilleszkedés, fluktuáció ELTE BTK Gazdaságpszichológiai Tanszék, elérhető: docplayer.hu/7337886-23-motivácio-megelegedettseg-beilleszkedes-fluktuacio-html, látogatva: 2016.10.24.

15. Sajtos L., Mitev A.: SPSS kutatási és adatelemzési kézikönyv, Alinea Kiadó, Budapest.

16. Sass J. (2011): Szervezeti érzelmek és szervezeti bizalom (tananyag), Budapest Corvinus Egyetem, Budapest, 2011, 19-29. 
17. Tóth A., Hunyadi ZS. (2009): Szülésznői motivációs és elégedettségi felmérés, Hivatásunk a Magyar Egészségügyi Szakdolgozói Kamara lapja 2009/3. 11-13.

18. Újváriné S. A., Takács P., Zrinyi M., Hajduné D.L., Radó S., Móricz I., Sárváry A. (2015): A Szabolcs-Szatmár-Bereg megyei ápolók szakmai továbbképzési motivációja és pályaképe, Acta Medicinae et Sociologica, Vol.6. No.16, 79-101.

\section{Internetes forrás:}

www.1.ekft.hu/juhaszistvan/human_ero_akt/a_munkavalvalo_elegedettseg.ppt (látogatva.2016.10.21.)

\section{Gebriné Éles Krisztina}

Tanársegéd a Debreceni Egyetem Egészségügyi Karán. Általános ápolói és aszszisztensi, OKJ szülésznői, BSc Ápoló és MSc Egészségügyi szociális munkás végzettsége van. 1998-2000-ig Vásárosnaményban dolgozott ápolónőként, majd 2000-2011-ig Nyíregyházán szülésznőként. 2011-ben a Pécsi Tudomány Egyetemen PhD tanulmányait megkezdte, 2014-ben abszolutóriumot szerzett. Kutatási területe: a szülésznők munkával való elégedettsége, életminősége, munkaérték megítélése, egészségmagatartása.

\section{Heinrichné Kőszegi Katalin}

Tanársegéd a Debreceni Egyetem Egészségügyi karán. Általános ápolói és aszszisztensi, szülésznői, egészségügyi szakoktatói, és egészségügyi szaktanári végzettséggel rendelkezik. 21 évet szülészeti osztályon dolgozott, szülésznőként, részlegfelelős szülésznőként. 2012-ben megkezdte $\mathrm{PhD}$ tanulmányait a Pécsi Tudomány Egyetem Egészségtudományi Karán, 2015-ben abszolutóriumot szerzett. Kutatási témája: roma kisebbség reprodukciós magatartása.

\section{Dr. Takács Péter}

Statisztikus, föiskolai docens, DE-EK minőségügyi vezető.2010-ben szerezte meg doktori fokozatát kriptográfiai protokollok formális ellenőrzése témakörben. Kutatási témakörei jórészt kapcsolódnak oktatási munkájához: statisztikai modellezés, biostatisztika, biometria; Rough Set Theory (RST); kutatásmódszertan; kriptográfia, protokollok, hálózatbiztonság; programozási nyelvek.

\section{Dr. Kósa Zsigmond}

A DE Egészségügyi Kar főiskolai tanára, Védőnői Módszertani és Népegészségtani Tanszék vezetöje. 2007-ben szerezte $\mathrm{PhD}$ fokozatát egészségtudományi területen a Debreceni Egyetem Népegészségügyi Karán. Kutatási tevékenységei 
közé tartozik a halandóság területi különbségeinek vizsgálata, morbiditási adatgyüjtési program kidolgozása, a telepszerü körülmények között élők egészségmagatartása, a telepszerü körülmények között élő iskoláskorúak egészségmagatartása, a bevándorlók egészségügyi ellátása.

\section{Dr. Lampek Kinga}

Habilitált főiskolai tanár a Pécsi Tudományegyetem Egészségtudományi Karán az Egészségfejlesztési és Népegészségtani Tanszék vezetője. Közgazdász, szociológus, kutatásai elsősorban az egészségszociológiai vizsgálatokra terjednek ki. Fő kutatási területei: népesség egészségi állapotát meghatározó társadalmi tényezők vizsgálata, az egészségügyben dolgozó szakalkalmazottak életminősége, munkával való elégedettsége, az idősödés társadalmi kihívásai. 
